A Platinum Open Access Journal for Organic Chemistry

Paper

Free to Authors and Readers

DOAJ Seal

Arkivoc 2021, part iii, 76-84

\title{
Synthesis bis-thienyl-substituted cyclobutenedione via the Liebeskind-Srogl and Stille cross-coupling reactions
}

Siddhant V. Kokate, ${ }^{a}$ Angélica Aguilar-Aguilar, ${ }^{a}$ Miguel A. Vázquez-Guevara, a Gabriel Luna-Bárcenas, ${ }^{\text {b }}$ Alejandro J. Gimenez, ${ }^{b}$ and Eduardo Peña-Cabrera*a

${ }^{a}$ Departamento de Química. Universidad de Guanajuato. Col. Noria Alta S/N. Guanajuato, Gto. 36050 Mexico

${ }^{b}$ Centro de Investigación y Estudios Avanzados del Instituto Politécnico Nacional Unidad Querétaro, QRO 76230 Mexico

Email: eduardop@ugto.mx

to Professor Lanny S. Liebeskind on the occasion of his 70th birthday

Received 12-23-2020

Accepted 01-19-2021

Published on line 02-01-2021

\section{Abstract}

Dithien-2-yl and bis(dithien-2-yl)-substituted cyclobutenediones were prepared via $\mathrm{Pd}(0)$-catalyzed crosscoupling reactions, namely, the Liebeskind-Srogl cross-coupling and Suzuki reactions in $85 \%$ and $82 \%$ yields, respectively.

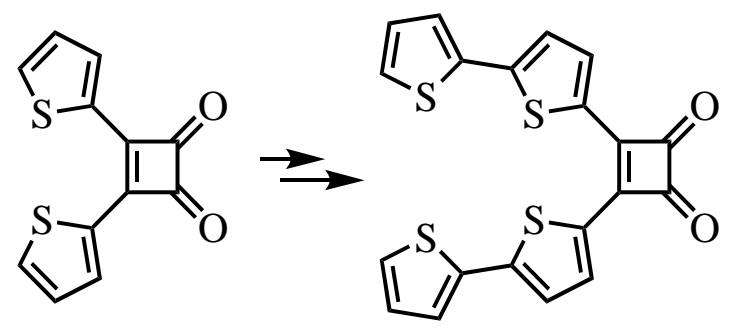

Keywords: Thiophene, cyclobutenediones, Liebeskind-Srogl cross-coupling, palladium 


\section{Introduction}

Oligothiophenes are among the most prominent $\pi$-conjugated organic oligomers. Their uses span molecular nanowires, ${ }^{1}$ organic dyes for molecular photovoltaics, ${ }^{2,3}$ organic field-effect transistors (OFET), ${ }^{4}$ and in general in molecular electronics..$^{5-8}$ Thiophenes are remarkable heterocycles which are endowed with very useful properties such as efficient charge transport, tunable redox potentials, and high polarizability. ${ }^{9-11}$ Donoracceptor (D-A) systems that contain thiophene units have become important over the last few years chiefly because of their useful properties. ${ }^{9-11}$ Herein, we present our efforts toward the synthesis of a novel derivative posessing a D-A architecture.

The design of bis(dithienyl)cyclobutenedione 1 was based upon two premises, i.e., (a) charge-separation is ensured by capping the thiophene chains with a cyclobutenedione (an electron-withdrawing fragment) and (b) if desired, cyclobutenedione could be transformed into either a quinone or a hydroquinone thereby changing the electronic and geometric features of 1 (Figure 1). ${ }^{12-15}$

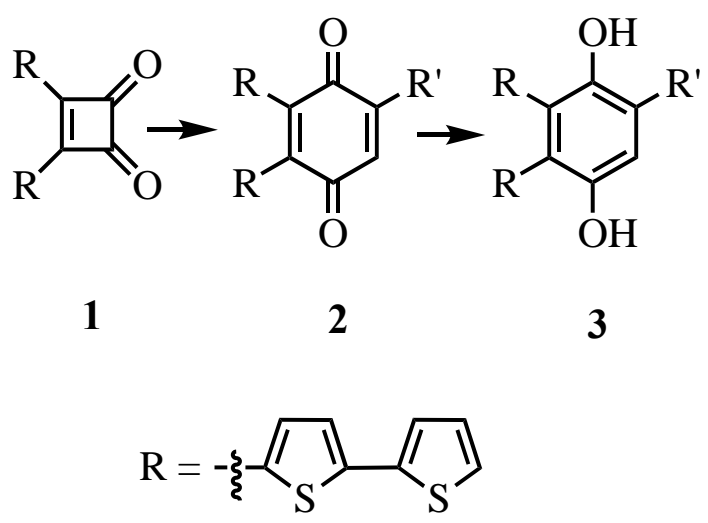

Figure1. Possible transformation of the cyclobutenedione nucleus.

Being aware of the importance of the cyclobutenedione synthetic transformations, over the last few years our research group has devoted a significant amount of effort to develop a methodology that would allow for the introduction of different aryl and heteroaryl substituents at the olefinic positions. ${ }^{16-17}$ In this contribution, we disclose the application of that methodology to achieve the synthesis of the thien-2-yl-cyclobutenedione derivatives.

\section{Results and Discussion}

Our initial efforts to prepare 7 focused on our recently developed cross-coupling of 3,4-bis-(4methoxyphenylthio)cyclobutenedione $\mathbf{4}$ with organoboron reagents to yield symmetric disubstituted cyclobutenediones. ${ }^{18}$ However, when this protocol was applied to the target molecule under a number of different reaction conditions, we always obtained a mixture of $\mathbf{4}$ and the mono- and bis-substituted products 6 ( $15 \%$ yield) and 7 (68\% yield) (Scheme 1 ). 
<smiles>COc1ccc(Sc2c(Sc3ccc(OC)cc3)c(=O)c2=O)cc1</smiles>

4, 1.0 equiv

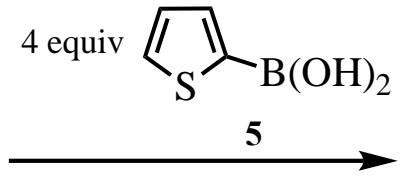

$2.5 \% \mathrm{Pd}_{2}(\mathrm{dba})_{3}, 7.5 \%$ TFP

5 equiv CuTC, THF, $55^{\circ} \mathrm{C}$<smiles>COc1ccc(Sc2c(-c3cccs3)c(=O)c2=O)cc1</smiles>

6, $15 \%$<smiles>O=c1c(-c2cccs2)c(-c2cccs2)c1=O</smiles>

7, $68 \%$<smiles>CC(C)c1ccc(P)s1</smiles>

\section{Scheme 1}

These results are in contrast to those observed with 3-thienylboronic acid 8, whereby under similar reaction conditions, isomer 9 was obtained in $94 \%$ yield (Scheme 2).

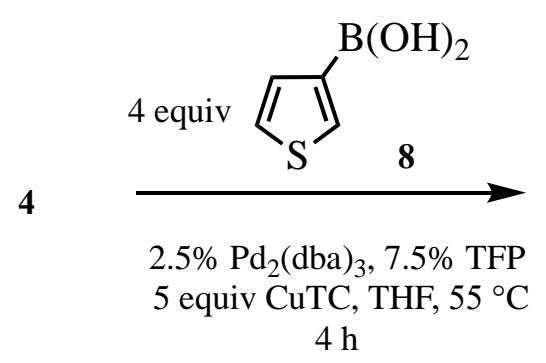

$4 \mathrm{~h}$

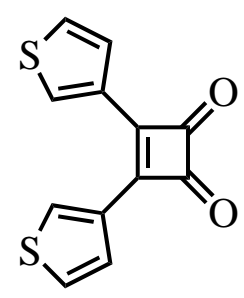

9, $94 \%$

\section{Scheme 2}

In view of these results, we decided to change our approach. The Suzuki cross-coupling between 2thienylboronic acid 5 and 3,4-dichloro-3-cyclobuten-1,2-dione ${ }^{19} 10$ ( $\mathrm{Pd}(\mathrm{OAc})_{2}, \mathrm{~S}-\mathrm{Phos}_{1} \mathrm{~K}_{3} \mathrm{PO}_{4}$ in toluene or THF) gave only traces of $\mathbf{7}$. Finally, 7 was efficiently prepared in $85 \%$ by using the Stille cross-coupling reaction ${ }^{20}$ between 3,4-dichloro-3-cyclobuten-1,2-dione 10 and commercially available tributyl(2-thienyl)stannane $\mathbf{1 1}$ (Scheme 3).<smiles>O=c1c(Cl)c(Cl)c1=O</smiles>

10, 1.0 equiv<smiles>CCCCCC(C)C(C)C(C)C</smiles>

11, 2.5 equiv<smiles>O=c1c(-c2cccs2)c(-c2cccs2)c1=O</smiles>

$7,85 \%$

\section{Scheme 3}

In order to incorporate the remaining thiophene units to $\mathbf{7}$ via a transition metal-catalyzed reaction, bromination of 7 was attempted with $\mathrm{Br}_{2}$ in $\mathrm{AcOH}$. However, even at $120{ }^{\circ} \mathrm{C}$, no reaction was observed, 
presumably, due to the deactivating effect of the electron-withdrawing cyclobutenedione unit. On the other hand, treatment of $\mathbf{7}$ with three equivalents of NBS in $\mathrm{AcOH}$ gave the desired product 12 in excellent yield (Scheme 4).

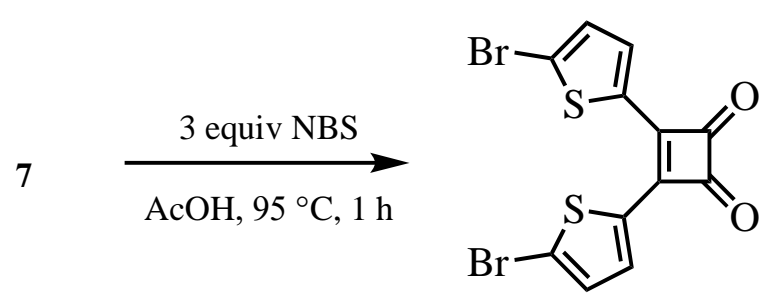

$12,97 \%$

\section{Scheme 4}

With dibromide 12 in hand, we proceeded to react it with 2-thienylboronic acid according to the Suzuki conditions reported by Buchwald ${ }^{20}$ (Scheme 5).

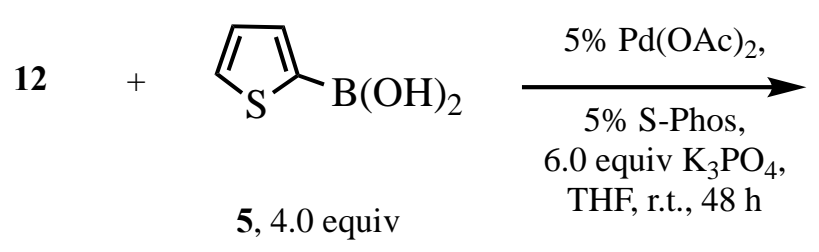<smiles>COc1cccc(OC)c1-c1ccccc1PN1CCCCC1</smiles>

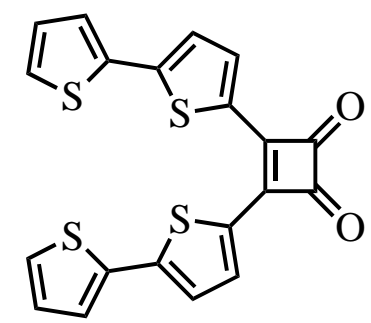

13, $82 \%$

\section{Scheme 5}

Despite the excellent results obtained using the Suzuki coupling to prepare 13, when the reaction was repeated at a larger scale, it became very sluggish with a significant amount of $\mathbf{1 2}$ remaining even after 3 days. We then turned our attention to the Stille coupling ${ }^{21-22}$ and carried out an optimization study for the synthesis of 13 (Table 1). 
Table 1. Optimization of the Stille Reaction for the Synthesis of $\mathbf{1 3}$

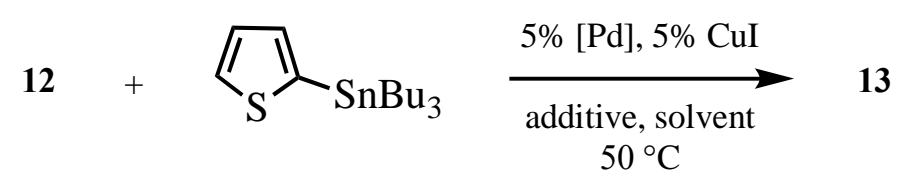

11, 2.5 equiv

\begin{tabular}{cccccc}
\hline $\begin{array}{c}\text { entr } \\
\mathrm{y}\end{array}$ & {$[\mathrm{Pd}]$} & $\begin{array}{c}\text { solven } \\
\mathrm{t}\end{array}$ & $\begin{array}{c}\text { additiv } \\
\mathrm{e}\end{array}$ & $\begin{array}{c}\text { Time } \\
(\mathrm{h})\end{array}$ & $\begin{array}{c}\% \text { yield } \\
\mathbf{1 3}^{\mathrm{a}}\end{array}$ \\
\hline 1 & $\mathrm{PdCl}_{2}\left(\mathrm{CH}_{3} \mathrm{CN}\right.$ & $\mathrm{CH}_{3} \mathrm{C}$ & - & 72 & $\mathrm{nr}$ \\
& )$_{2}$ & $\mathrm{~N}$ & & & \\
2 & $\mathrm{PdCl}_{2}\left(\mathrm{PPh}_{3}\right)_{2}$ & $\mathrm{THF}$ & - & 2 & 75 \\
3 & $\mathrm{PdCl}_{2}\left(\mathrm{PPh}_{3}\right)_{2}$ & $\mathrm{DMF}$ & - & 1.5 & 84 \\
4 & $\mathrm{PdCl}_{2}\left(\mathrm{PPh}_{3}\right)_{2}$ & $\mathrm{THF}$ & $4.0 \mathrm{CsF}$ & 2 & 77 \\
5 & $\mathrm{PdCl}_{2}\left(\mathrm{PPh}_{3}\right)_{2}$ & $\mathrm{DMF}$ & $4.0 \mathrm{CsF}$ & $10 \mathrm{~min}$ & 80 \\
\hline
\end{tabular}

a isolated yields.

The beneficial effect that fluoride has in the Stille reaction ${ }^{23}$ was observed in this system as well, for 13 was isolated in $80 \%$ yield after only $10 \mathrm{~min}$.

During the isolation and characterization of $\mathbf{1 3}$ we made an interesting observation. Once in solution (hexanes/EtOAc) and exposed to air, [13 remained unchanged if the solution remained under $\mathrm{N}_{2}$ ] the originally orange solution of $\mathbf{1 3}$ gradually turned deep red. TLC of this solution showed that $\mathbf{1 3}$ slowly transformed into a different compound. ${ }^{1} \mathrm{H}$ NMR of the new compound was not very informative since it displayed the same signals as 13, only slightly shifted. However, ${ }^{13} \mathrm{C}$ NMR of this material showed no carbonyl signal in the region typical of cyclobutenediones (190-200 ppm), it did, however, show a signal of a carbonyl group at $164.6 \mathrm{ppm}$, which is typical of anhydride carbonyl groups ( $C=0$ signal of maleic anhydride appears at 164.5 ppm). Based upon this information, it is believed that oxygen inserted between the carbonyl groups of $\mathbf{1 3}$ (Scheme 6).

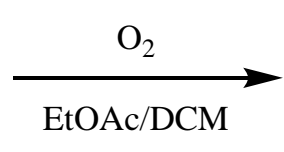<smiles>O=C1OC(=O)C(c2ccc(-c3cccs3)s2)=C1c1ccc(-c2cccs2)s1</smiles>

14, quantitative yield

\section{Scheme 6}

In addition to the spectral data described above, HRMS analysis gives a molecular peak that matches the structure proposed. This oxidation reaction is not unprecedented. Tidwell and Zhao ${ }^{24}$ showed that bisketene 16, generated either thermally or photochemically from its corresponding cyclobutenedione precursor, formed the substituted maleic anhydride on exposure to oxygen (Scheme 7). 


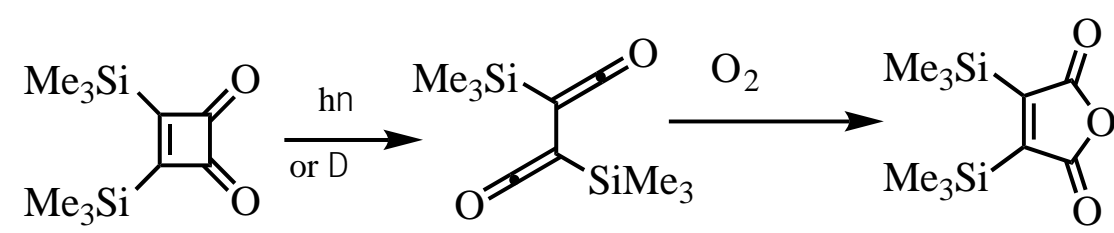

15

16

17

Scheme 7. Insertion of oxygen into cyclobutenediones.

A similar process may be operating in the transformation depicted in eq 6 . It is important to notice that this process takes place only after two more thiophene units have been incorporated to 7 . This seems to indicate that extension of the conjugated system activates the cyclobutenedione ring toward oxygen insertion.

\section{Conclusions}

An efficient methodology to prepare a D-A system comprising two bis-thienyl groups attached to a cyclobutenedione has been developed. Both the Liebeskind-Srogl and Stille cross-coupling reactions were attempted to furnish the target molecule, the latter being the method that gave the best results. The addition of CsF to the key Stille reaction was crucial to the success of the synthesis of $\mathbf{1 3}$. When $\mathbf{1 3}$ was exposed to air, the corresponding anhydride $\mathbf{1 7}$ was smoothly formed by the insertion of oxygen between the carbonyl groups. This transformation is currently under study in our laboratory and the results will be reported in due course.

\section{Experimental Section}

General. ${ }^{1} \mathrm{H}$ and ${ }^{13} \mathrm{C}$ NMR spectra were recorded in deuteriochloroform $\left(\mathrm{CDCl}_{3}\right)$, with either tetramethylsilane (TMS) $\left(0.00 \mathrm{ppm}{ }^{1} \mathrm{H}, 0.00 \mathrm{ppm}{ }^{13} \mathrm{C}\right)$, chloroform $\left(7.26 \mathrm{ppm}{ }^{1} \mathrm{H}, 77.00 \mathrm{ppm}{ }^{13} \mathrm{C}\right)$. Data are reported in the following order: chemical shift in ppm, multiplicities (br (broadened), s (singlet), $d$ (doublet), $t$ (triplet), $q$ (quartet), $m$ (multiplet), exch (exchangeable), app (apparent)), coupling constants, $J(\mathrm{~Hz})$, and integration. Infrared spectra were recorded on a FTIR spectrophotometer. Peaks are reported $\left(\mathrm{cm}^{-1}\right)$ with the following relative intensities: $s$ (strong, 67-100 \%), $m$ (medium, 40-67\%), and w (weak, 20-40\%). Melting points are not corrected. TLC was conducted in silica gel on Al foils. Detection was by UV light ( 254 or $365 \mathrm{~nm}$ ). HRMS samples were ionized by ESI+ and recorded via the TOF method.

Synthesis of 3,4-Bis(thien-2-yl)-3-cyclobuten-1,2-dione 7 using the Liebeskind-Srogl cross-coupling. A $50 \mathrm{~mL}$ Schlenk flask under $\mathrm{N}_{2}$ was charged with $4(100 \mathrm{mg}, 0.28 \mathrm{mmol}, 1.0$ equiv), thienylboronic acid $5(142.8 \mathrm{mg}$, $1.1 \mathrm{mmol}, 4.0$ equiv), and anhyd THF (10 mL), and the resulting yellow solution was deoxygenated by bubbling $\mathrm{N}_{2}$ for $5 \mathrm{~min}$. Then, CuTC (266 mg, $1.4 \mathrm{mmol}, 5.0$ equiv), $\mathrm{Pd}_{2}(\mathrm{dba})_{3}\left(6.4 \mathrm{mg}, 2.5 \times 10^{-3} \mathrm{mmol}\right.$ ), and trifurylphosphine $\left(4.9 \mathrm{mg}, 7.5 \times 10^{-3} \mathrm{mmol}\right)$ were added. The reaction mixture was heated at $55^{\circ} \mathrm{C}$ for $22 \mathrm{~h}$, the heating bath was removed, and the volatiles were removed in vacuo. The crude material was purified by flash chromatography $\left(\mathrm{SiO}_{2}\right.$ gel, $5 \%$ ethyl acetate/hexanes gradient) to give the product as a yellow solid (46.7 $\mathrm{mg}, 68 \%$ ). Recrystallization was carried out by using $\mathrm{DCM} /$ cold petroleum ether. $\mathrm{Mp} \mathrm{200-201}{ }^{\circ} \mathrm{C} ; \mathrm{TLC}\left(\mathrm{SiO}_{2}\right.$, 
20\% EtOAc/hexanes, $R f=0.4)$; IR (KBr, cm $\left.{ }^{-1}\right): 3108.4(\mathrm{w}), 3085$ (d), $1764(\mathrm{~s}), 1567$ (s), $1417(\mathrm{~m}), 1405(\mathrm{~m}) ;{ }^{1} \mathrm{H}$ NMR (500 MHz, CDCl 3 ): $\delta 8.43\left(\mathrm{dd}, J 3.8,0.9 \mathrm{~Hz}, 2 \mathrm{H}\right.$ ), 7.96 (dd, J 5.0, 0.9 Hz, 2H), 7.39 (dd, J 4.9, $3.9 \mathrm{~Hz}, 2 \mathrm{H}$ ); ${ }^{13} \mathrm{C}$ NMR $\left(126 \mathrm{MHz}, \mathrm{CDCl}_{3}\right) \delta 193.0,173.2,135.2,134.0,129.3,129.3 ; \mathrm{HRMS}\left(\mathrm{C}_{12} \mathrm{H}_{7} \mathrm{O}_{2} \mathrm{~S}_{2}, \mathrm{M}+1 \mathrm{H}\right)$ calcd. 246.9882, found 246.9883. Along with 7, the mono-coupled product 6 was isolated $(13.0 \mathrm{mg}, 15 \%)$ as a yellow solid. ${ }^{1} \mathrm{H}$ NMR (500 MHz, CDCl $) \delta 7.97(d, J 3.4 \mathrm{~Hz}, 1 \mathrm{H}), 7.91(\mathrm{~d}, J 5.0 \mathrm{~Hz}, 1 \mathrm{H}), 7.56(\mathrm{~d}, J 8.7 \mathrm{~Hz}, 2 \mathrm{H}), 7.35-7.33(\mathrm{t}, 1 \mathrm{H})$, $6.97(\mathrm{~d}, J 8.7 \mathrm{~Hz}, 2 \mathrm{H}), 3.86(\mathrm{~s}, 3 \mathrm{H})$.

Synthesis of 3,4-Bis(thien-2-yl)-3-cyclobuten-1,2-dione 7 using the Stille cross-coupling. A $100 \mathrm{~mL}$ two-neck round bottom flask was charged with thien-2-yl stannane 6 (1.6 g, 4.29 mmol, 2.5 equiv), $\mathrm{CH}_{3} \mathrm{CN}(16 \mathrm{~mL})$, and a stir bar under $\mathrm{N}_{2}$. The reaction mixture was purged with $\mathrm{N}_{2}$ during 5 min after which dichlorocyclobutenedione 3 (261.7 mg, $1.73 \mathrm{mmol}, 1$ equiv), $\mathrm{PdCl}_{2}\left[\mathrm{CH}_{3} \mathrm{CN}\right]_{2}$ (22.2 $\mathrm{mg}, 0.09 \mathrm{mmol}, 5 \mathrm{~mol} \%$ ) and Cul $(16.6 \mathrm{mg}, 0.09 \mathrm{mmol}, 5 \mathrm{~mol} \%)$ were added. The reaction mixture was heated at $70{ }^{\circ} \mathrm{C}$ for $3.5 \mathrm{~h}$ then it was allowed to reach $r$. Once the reaction mixture reached $r t$, an abundant yellow precipitate formed. The acetonitrile volume was doubled, and the solid dissolved completely. The acetonitrile layer was extracted with hexanes $(3 \times 15 \mathrm{~mL})$ to eliminate the tin by-products, then the solvent was evaporated under reduced pressure. The final product was purified by flash chromatography $\left(\mathrm{SiO}_{2}\right.$-gel) using an AcOEt/hexanes gradient. The resulting solid was washed with hexanes $(3 \times 15 \mathrm{~mL})$ and dried under vacuum. The product (359.7 mg, $1.46 \mathrm{mmol}, 85 \%)$ was obtained as yellow crystalline solid. Mp 200-201 ${ }^{\circ} \mathrm{C}$.

Synthesis of 3,4-Bis(5-bromothien-2-yl)cyclobut-3-ene-1,2-dione 12. A $50 \mathrm{~mL}$ Schlenk tube under $\mathrm{N}_{2}$ was charged with 7 (20 mg, $0.0812 \mathrm{mmol}, 1.0$ equiv.), $N$-bromosuccinimide (43.36 mg, $0.2436 \mathrm{mmol}, 3.0$ equiv.), glacial acetic acid $(3.0 \mathrm{~mL})$. The reaction mixture was stirred at $\mathrm{rt}$ for $5 \mathrm{~min}$, then heated at reflux at $95^{\circ} \mathrm{C}$ for 1 $h$, after which it was allowed to reach rt. An abundant yellow solid was observed. A saturated aq $\mathrm{NH}_{4} \mathrm{Cl}$ solution was added $(4 \mathrm{~mL})$ followed by $0.25 \mathrm{M} \mathrm{NaOH}(4 \mathrm{~mL})$ and stirring continued for $10 \mathrm{~min}$. The yellow solid was filtered using a Whatmann filter paper and washed with $0.1 \mathrm{M} \mathrm{NaOH}(4 \times 5 \mathrm{~mL})$ and then with $\mathrm{H}_{2} \mathrm{O}(2 \times 5$ $\mathrm{mL}$ ). The yellow solid was dried under vacuum (31.6 mg, 97\% yield). Recrystallization was carried out using $\mathrm{DCM} /$ cold petroleum ether. Mp 192-193 ${ }^{\circ} \mathrm{C}$; TLC (30\% EtOAc/Hexanes, $\left.R f=0.7\right) ; \mathrm{IR}\left(\mathrm{KBr}, \mathrm{cm}^{-1}\right): 3095(\mathrm{w}), 1786$ (s), 1761 (s), $1584(\mathrm{~m}), 1411(\mathrm{~m}) ;{ }^{1} \mathrm{H}$ NMR (500 MHz, CDCl $) \delta 8.13$ (d, J 3.8, 2H), 7.35 (d, J 3.9, 2H); ${ }^{13} \mathrm{C} \mathrm{NMR}$ $\left(126 \mathrm{MHz}, \mathrm{CDCl}_{3}\right) \delta 192.2,171.2,134.4,132.5,130.7,124.9 ; \mathrm{HRMS}\left(\mathrm{C}_{12} \mathrm{H}_{5} \mathrm{Br}_{2} \mathrm{O}_{2} \mathrm{~S} 2, \mathrm{M}+1 \mathrm{H}\right)$ calcd. 404.8100, found 404.8071 .

Synthesis of 3,4-bis([2,2'-bithien]-5-yl)cyclobut-3-ene-1,2-dione 13. A $25 \mathrm{~mL}$ Schlenk tube under $\mathrm{N}_{2}$ was charged with 12 (20 mg, $0.0498 \mathrm{mmol}, 1.0$ equiv), $\mathrm{PdCl}_{2}\left(\mathrm{PPh}_{3}\right)_{2}$ (1.74 mg, $\left.0.0025 \mathrm{mmol}, 5 \mathrm{~mol} \%\right), \mathrm{Cul}$ (0.47 mg, $0.0025 \mathrm{mmol} 5 \mathrm{~mol} \%), \mathrm{CsF}$ (30.24 mg, $0.1991 \mathrm{mmol}, 4.0$ equiv), DMF (4 mL). The reaction was stirred at rt for $1 \mathrm{~min}$ after which 2-(tributylstannyl)thiophene 11 was added (47 mg, $0.1244 \mathrm{mmol}, 2.5$ equiv). The reaction mixture was stirred at $50{ }^{\circ} \mathrm{C}$ for $10 \mathrm{~min}$. After $10 \mathrm{~min}$., the reaction was allowed to reach $\mathrm{rt}$ and quenched by adding $\mathrm{Et}_{2} \mathrm{O}(15 \mathrm{~mL})$ and equal volume of $\mathrm{H}_{2} \mathrm{O}$. The aqueous layer was extracted with $\mathrm{Et}_{2} \mathrm{O}(5 \times 15 \mathrm{~mL})$ and the organic layers were combined and dried over $\mathrm{MgSO}_{4}$. The mixture was filtered through a cotton plug and concentrated under reduced pressure to get a red colored oily material. After trituration with hexanes, a red solid formed, which was washed futher with hexanes $(10 \times 5 \mathrm{~mL})$ to remove tin impurities. Finally, the material was washed with $2.5 \% \mathrm{EtOAc} /$ hexanes $(5 \mathrm{~mL})$ to give the final product $(16.4 \mathrm{mg}, 80 \%) . \mathrm{Mp}>196{ }^{\circ} \mathrm{C}$ (dec); TLC (30\% EtOAc/Hexane, $R f=0.5)$; IR $\left(\mathrm{KBr}, \mathrm{cm}^{-1}\right): 3098(\mathrm{w}), 1756(\mathrm{~s}), 1572(\mathrm{~m}), 1438(\mathrm{~s}) ;{ }^{1} \mathrm{H} \mathrm{NMR}\left(500 \mathrm{MHz} \mathrm{CDCl}_{3}\right)$ $\delta 8.33(\mathrm{~d}, J 4.1 \mathrm{~Hz}, 2 \mathrm{H}), 7.46(\mathrm{dd}, J 3.6,0.9 \mathrm{~Hz}, 2 \mathrm{H}), 7.44-7.41(\mathrm{~m}, 4 \mathrm{H}), 7.13(\mathrm{dd}, J 5.1,3.7 \mathrm{~Hz}, 2 \mathrm{H}) ;{ }^{13} \mathrm{C} \mathrm{NMR}$

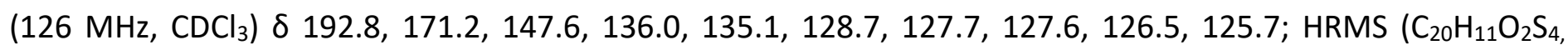
$\mathrm{M}+1 \mathrm{H}$ ) calcd 410.9636, found 410.9639 . 
Synthesis of 2,3-bis(5-[2,2']-bithien-5-yl) maleic anhydride 14. Compound 13 (49 mg, 0.1192 mmol) was dissolved in a $1: 1$ AcOEt:DCM mixture $(20 \mathrm{~mL})$ in a beaker. The reaction mixture was stirred at $\mathrm{rt}$ under air for 5 days, solvent was replenished when necessary to avoid dryness. After evaporation of the solvent the dark red colored compound 14 was obtained (50.9 mg, 100\%). M.p.= 186-187 ${ }^{\circ} \mathrm{C}$. TLC (30\% EtOAc/Hexane, Rf = 0.54); IR ( $\left.\mathrm{KBr}, \mathrm{cm}^{-1}\right)$ : 3108 (d), 1745 (s), 1439 (s); ${ }^{1} \mathrm{H}$ NMR (500 MHz, CDCl 3 ) $\delta 7.99$ (d, J $\left.4.1 \mathrm{~Hz}, 2 \mathrm{H}\right), 7.34$ (dd, J 6.7, 4.4 Hz, 4H), 7.25 (d, J $4.1 \mathrm{~Hz}, 2 \mathrm{H}), 7.08$ (dd, J 5.0, $3.8 \mathrm{~Hz}, 2 \mathrm{H}) ;{ }^{13} \mathrm{C} \mathrm{NMR}\left(126 \mathrm{MHz}, \mathrm{CDCl}_{3}\right) \delta 164.4,144.6$, 136.0, 134.0, 128.4, 127.3, 126.7, 126.7, 125.7, 124.4; HRMS $\left(\mathrm{C}_{20} \mathrm{H}_{11} \mathrm{O}_{3} \mathrm{~S}_{4}, \mathrm{M}+1 \mathrm{H}\right)$ calcd 426.9600, found 426.9586.

\section{Acknowledgements}

Financial support from CONACYT (grant 253623) and US Army (grant W911NF1810428) is acknowledged. S.V.K. thanks CONACyT for graduate scholarship.

\section{Supplementary Material}

${ }^{1} \mathrm{H},{ }^{13} \mathrm{C}$ spectra of the compounds prepared are available as supplementary material.

\section{References}

1. Sumi, N.; Nakanishi, H.; Ueno, S.; Takimiya, K.; Aso, Y.; Otsubo, T. Bull. Chem. Soc. Jpn. 2001, 74, 979. https://doi.org/10.1246/bcsj.74.979

2. Kuomura, N.; Wang, Z.-S.; Mori. S.; Miyashita, M.; Suzuki, E.; Hara, K. J. Am. Chem. Soc. 2006, $128,14256$. https://doi.org/10.1021/ja0645640

3. Sun, Y.; Welch, G. C.; Leong, W. L.; Takacs, C. J.; Bazan, G. C.; Heeger, A. J. Nat. Mater. 2002, 11, 44-48. https://doi.org/10.1038/nmat3160

4. Torsi, L.; Magliulo, M.; Manoli, L.; Palazzo, G. Chem. Soc. Rev. 2013, 42, 8612-8628. https://doi.org/10.1039/c3cs60127g

5. Bäuerle, P. In Electronic Materials: The Oligomer Approach, Müllen, K.; Wegner, G., Eds.; Wiley-VCH: Weinheim, Germany, 1998; pp 105. https://doi.org/10.1002/9783527603220

6. Mishra, A.; Ma, C.-Q.;Bäuerle, P. Chem. Rev. 2009, 109, 1141. https://doi.org/10.1021/cr8004229

7. Perepichka, I. F.; Perepichka, D. F. Handbook of Thiophene-based Materials: Applications in Organic Electronics and Photonics; Wiley- VCH: Weinheim, 2009.

https://doi.org/10.1002/9780470745533

8. Klauk, H. Organic Electronics; Wiley-VCH: Weinheim, Germany, 2006. https://doi.org/10.1002/3527608753

9. Beaujuge, P. M.; Amb, C. M.; Reynolds, J. R. Acc. Chem. Res. 2010, 43, 1396-1407. https://doi.org/10.1021/ar100043u 
10. Fang, Z.; Eshbaugh, A. A.; Schanze, K. S. J. Am. Chem. Soc. 2011, 133, 3063-3069. https://doi.org/10.1021/ja109926k

11. Patel, D. G.; Feng, F.; Ohnishi, Y.-y.; Abboud, K. A.; Hirata, S.; Schanze, K. S.; Reynolds, J. R. J. Am. Chem. Soc. 2012, 134, 2599-2612.

https://doi.org/10.1021/ja207978v

12. Knueppel, D.; F. Martin, S. F. Angew. Chem. Int. Ed. 2009, 48, 2569-2571, https://doi.org/10.1002/anie.200806269

13. Liebeskind, L. S.; lyer, S.; Jewell, C. F. J. Org. Chem. 1986, 51, 3065-3067. https://doi.org/10.1021/jo00365a043

14. Liebeskind, L. S. Tetrahedron Lett. 1989, 45, 3053-3060. https://doi.org/10.1016/S0040-4020(01)80131-9

15. Liebeskind, L. S.; Iyer, S.; Jewell Jr. C. F.; J. Org. Chem. 1986, 51, 3065-3067, https://doi.org/10.1021/j000365a043

16. Aguilar-Aguilar, A.; Liebeskind, L. S.; Peña-Cabrera, E. J. Org. Chem. 2007, 72, 8539-8542. https://doi.org/10.1021/jo701331m

17. Compound $\mathbf{7}$ was recently prepared using similar methodology. See: Ohishi, T.; Sone, T.; Oda, K.; Yokoyama, A. RSC Adv. 2019, 9, 40863-40872. https://doi.org/10.1039/C9RA08275A

18. Miyaura, N. J. Organomet. Chem. 2002, 653, 54-57. https://doi.org/10.1016/S0022-328X(02)01264-0

19. Lunelli, S. Tetrahedron Lett. 2007, 48, 3595-3597. https://doi.org/10.1016/j.tetlet.2007.03.091

20. Walker, S. D.; Barder, T. E.; Martinelli, J. R.; Buchwald, S. L. Angew. Chem. Int. Ed. 2004, 43, 1871. https://doi.org/10.1002/anie.200353615

21. Liebeskind, L. S.; Fengl, R. W. J. Org. Chem. 1990, 55, 5359-5364. https://doi.org/10.1021/jo00306a012

22. Farina, V.; Kapadia, S.; Krishnan, B.; Wang, C.; Liebeskind, L. S. J. Org. Chem. 1994, 59, 5905 - 5911. https://doi.org/10.1021/jo00099a018

23. Mee, S. P. H.; Lee, V.; Baldwin, J. E. Angew. Chem. Int. Ed. 2004, 43, $1132-1132$. https://doi.org/10.1002/anie.200352979

24. Zhao, D.; Tidwell, T. T. J. Am. Chem. Soc. 1992, 114, 10980. https://doi.org/10.1021/ja00053a055 